\title{
Milk fat depression induced by dietary marine algae in dairy ewes: Persistency of milk fatty acid composition and animal performance responses
}

\author{
E. Bichi, ${ }^{*}$ G. Hervás, ${ }^{*}$ P. G. Toral, ${ }^{*}$ J. J. Loor, †‡ and P. Frutos ${ }^{* 1}$ \\ *Instituto de Ganadería de Montaña (CSIC-ULE), Finca Marzanas s/n. 24346 Grulleros, León, Spain \\ †Mammalian NutriPhysioGenomics Laboratory, Department of Animal Sciences, and \\ ‡Division of Nutritional Sciences, University of Illinois, Urbana 61801
}

\begin{abstract}
Addition of marine algae (MA) to the diet of dairy ruminants has proven to be an effective strategy to enhance the milk content of some bioactive lipids, but it has also been associated with the syndrome of milk fat depression. Little is known, however, about the persistency of the response to dietary MA in sheep. Based on previous experiments with dairy ewes fed sunflower oil plus MA, it was hypothesized that the response might be mediated by time-dependent adaptations of the rumen microbiota, which could be evaluated indirectly through milk fatty acid (FA) profiles. Animal performance and milk FA composition in response to MA in the diet were studied using 36 Assaf ewes distributed in 6 lots and allocated to 2 treatments (3 lots/ treatment) consisting of a total mixed ration (40:60 forage:concentrate ratio) supplemented with $25 \mathrm{~g}$ of sunflower oil $(\mathrm{SO}) / \mathrm{kg}$ of dry matter plus 0 ( $\mathrm{SO}$; control diet) or $8 \mathrm{~g}$ of $\mathrm{MA} / \mathrm{kg}$ of dry matter (SOMA diet). Milk production and composition, including FA profile, were analyzed on d $0,6,12,18,24,34,44$, and 54 of treatment. Diet supplementation with MA did not affect milk yield but did decrease milk fat content. Differences in the latter were detected from d 18 onward and reached $-17 \%$ at the end of the experiment (i.e., on d 54). Compared with the control diet, the SOMA diet caused a reduction in milk 18:0 and its desaturation product (cis-9 18:1) that lasted for the whole experimental period. This decrease, together with the progressive increase in some putative fat synthesis inhibitors, especially trans-10 18:1, was related to the persistency of milk fat depression in lactating ewes fed MA. Additionally, inclusion of MA in the diet enhanced the milk content of trans-11 18:1, cis-9,trans-11 18:2, and C20-22 n-3 polyunsaturated FA, mainly 22:6 n-3. Overall, the persistency of the responses observed sug-
\end{abstract}

Received June 26, 2012.

Accepted September 8, 2012.

${ }^{1}$ Corresponding author: p.frutos@csic.es gests that the ruminal microbiota did not adapt to the dietary supply of very long chain n-3 polyunsaturated fatty acids.

Key words: conjugated linoleic acid, lipid supplementation, sheep, trans fatty acid

\section{INTRODUCTION}

Addition of marine algae (MA) to the diet of dairy ruminants is an effective strategy to enhance the milk content of bioactive lipids such as n-3 PUFA or conjugated linoleic acid (CLA; Franklin et al., 1999; Reynolds et al., 2006). This approach in cows has also been associated with a severe decline in milk fat content (Franklin et al., 1999; Boeckaert et al., 2008a). Although the syndrome of milk fat depression (MFD) in ewes was not first described in response to MA (Papadopoulos et al., 2002; Reynolds et al., 2006), Toral et al. (2010b) recently observed that dietary supplementation with $2.5 \%$ sunflower oil plus incremental amounts of MA $(0.8,1.6$, and $2.4 \%)$ strongly reduced milk fat content. Based on comparison with the diet supplemented with sunflower oil only, those authors attributed the MFD to the addition of MA as reflected by changes in milk FA profile. Those changes included not only an enrichment in some potentially healthy FA (e.g., trans-11 18:1, cis-9,trans-11 18:2, and 22:6 n-3) but also a marked increase in trans-10 18:1, whose effect on human health is uncertain (see review by Gebauer et al., 2011). Although some results seem contradictory (Lock et al., 2007), trans-10 18:1 has been proposed as a putative cause of MFD (Griinari et al., 1998; Loor et al., 2005a; Shingfield et al., 2009).

Interestingly, after $28 \mathrm{~d}$ on the diet supplemented with sunflower oil plus the lowest dose of MA (0.8\%), Toral et al. (2010b) observed a decrease in milk trans-10 18:1 concentration as well as in trans-9,cis-11 18:2. Both FA arise from alternative rumen microbial biohydrogenation pathways and have been related to MFD in dairy cows (Perfield et al., 2007; Shingfield et al., 2009). This occurred together with a slight but significant increase 
in milk fat content. Analysis of the FA composition of the ruminal digesta (Toral et al., 2012) confirmed a lower content of trans-10 18:1 and suggested an adaptation of the rumen bacterial community to the consumption of MA and a potential reestablishment of the main pathway of biohydrogenation. If this is true and the response to marine lipid supplementation varies over time, a longer-term study would be necessary to evaluate time-dependent variations. Therefore, the main objective of this study was to evaluate animal performance and milk FA composition in dairy ewes over a 54-d period, with the aim of studying the persistency of the response to the addition of MA to a diet rich in linoleic acid.

\section{MATERIALS AND METHODS}

\section{Animals, Experimental Diets, and Management}

All experimental procedures were performed in accordance with the Spanish Royal Decree 1201/2005 for the protection of animals used for experimental and other scientific purposes. Thirty-six Assaf ewes (84.5 \pm $1.68 \mathrm{~kg}$ of BW) in mid lactation $(82 \pm 0.9 \mathrm{DIM}$ at the beginning of the experiment) were stratified according to milk yield, BW, days postpartum, lactation number, and milk fat content, and randomly distributed in 6 lots (6 ewes/lot), which in turn were assigned to 1 of 2 dietary treatments (3 lots/treatment). Diets consisted of a TMR based on alfalfa hay and a concentrate (40:60) supplemented with $25 \mathrm{~g}$ of sunflower oil (Carrefour S.A., Madrid, Spain)/kg of DM plus 0 (SO; control diet) or $8 \mathrm{~g}$ of marine algae (DHA Gold Animal Feed Ingredient, Martek Biosciences Corp., Columbia, MD)/ $\mathrm{kg}$ of DM (SOMA diet). The ingredients and chemical composition of the experimental diets, which were prepared weekly and included molasses to reduce selection of dietary components, are presented in Table 1. Ewes were fed the control diet during $20 \mathrm{~d}$ of adaptation before the start of the study. Fresh diets were offered daily ad libitum at 0900 and $1900 \mathrm{~h}$, and clean water was always available. Ewes were milked twice daily at 0830 and $1830 \mathrm{~h}$ in a $1 \times 10$ stall milking parlor (DeLaval, Madrid, Spain) throughout the $54 \mathrm{~d}$ experiment.

\section{Measurements and Sampling}

Intake of DM was recorded every $4 \mathrm{~d}$ for each experimental lot by weighing the amount of DM offered and refused by each lot. Samples of the diets and refusals were collected with the same frequency, stored at $-30^{\circ} \mathrm{C}$, and then freeze-dried.

Individual daily milk yields were recorded on $\mathrm{d} 0$, $6,12,18,24,34,44$, and 54. Milk samples were col- lected with the same frequency from each ewe and composited according to morning and evening milk yield. One aliquot was stored at $4^{\circ} \mathrm{C}$ with natamycin $(\mathrm{D} \& \mathrm{~F}$ Control Systems Inc., Dublin, CA) until analyzed for fat, protein, lactose, and TS. Milk FA composition was determined in untreated samples from each experimental lot, which were composited according to individual milk yield and stored at $-30^{\circ} \mathrm{C}$ until analysis.

\section{Chemical Analysis}

Samples of TMR were analyzed for DM (ISO 6496; ISO, 1999a), ash (ISO 5984; ISO, 2002), and CP (ISO 5983-2; ISO, 2009). Neutral and acid detergent fiber were determined as described by Mertens (2002) and AOAC International (2006; method 973.18), respectively, using an Ankom ${ }^{2000}$ fiber analyzer (Ankom Technology Corp., Macedon, NY). Neutral detergent fiber was assayed with sodium sulfite and $\alpha$-amylase and expressed with residual ash (the latter also for ADF). The content of ether extract in the diets was determined by the Ankom filter bag technology (AOCS, 2008; Procedure Am 5-04). Milk CP, lactose, fat, and TS contents were determined by infrared spectrophotometry (ISO 9622; ISO, 1999b), using a MilkoScan 255 A/S N (Foss Electric, Hillerød, Denmark).

Fatty acid methyl esters (FAME) in freeze-dried samples of TMR were prepared in a one-step extractiontransesterification procedure using chloroform and $2 \%$ (vol/vol) sulfuric acid in methanol (Shingfield et al., 2003), with tridecanoic acid (Sigma-Aldrich, Madrid, Spain) as an internal standard. For milk FA composition analysis, lipids in $1 \mathrm{~mL}$ of milk were extracted using diethyl ether:hexane $(5: 4, \mathrm{vol} / \mathrm{vol})$ and transesterified to FAME using freshly prepared methanolic sodium methoxide, as outlined by Shingfield et al. (2003), with tridecanoic acid as an internal standard. Methyl esters were separated and quantified using a gas chromatograph (7890A GC System, Agilent Technologies, Santa Clara, CA) equipped with a flame-ionization detector and a $100-\mathrm{m}$ fused-silica capillary column $(0.25 \mathrm{~mm}$ i.d., $0.2 \mu \mathrm{m}$ film thickness; CP-SIL 88, Chrompack 7489, Varian Ibérica S.A., Madrid, Spain) and He as the carrier gas. Total FAME profile in a $2-\mu \mathrm{L}$ sample volume at a split ratio of 1:50 was determined using a temperature gradient program (Shingfield et al., 2003). Isomers of 18:1 were further resolved in a separate analysis under isothermal conditions at $170^{\circ} \mathrm{C}$ (Shingfield et al., 2003). Peaks were identified based on retention time comparisons with authentic standards (from $\mathrm{Nu}-$ Chek Prep., Elysian, MN; Sigma-Aldrich; and Larodan Fine Chemicals AB, Malmö, Sweden). Identification of FA was verified based on FAME standard mixtures when available, chromatograms reported in the litera- 
Table 1. Ingredients and chemical composition of the experimental $\operatorname{diets}^{1}$

\begin{tabular}{|c|c|c|c|c|}
\hline Item & $\mathrm{SO}$ & SOMA & $\mathrm{SED}^{2}$ & $P$-value \\
\hline \multicolumn{5}{|l|}{ Ingredient, $\mathrm{g} / \mathrm{kg}$ of fresh matter } \\
\hline Dehydrated alfalfa hay & 392 & 389 & & \\
\hline Whole corn grain & 184 & 183 & & \\
\hline Soybean meal & 147 & 146 & & \\
\hline Whole barley grain & 119 & 118 & & \\
\hline Beet pulp & 66 & 65 & & \\
\hline Molasses & 48 & 48 & & \\
\hline Feed supplement $^{3}$ & 23 & 23 & & \\
\hline Sunflower oil $^{4}$ & 21 & 21 & & \\
\hline Marine algae $^{5}$ & 0 & 7 & & \\
\hline \multicolumn{5}{|l|}{ Chemical composition, $\mathrm{g} / \mathrm{kg}$ of $\mathrm{DM}$} \\
\hline $\mathrm{OM}$ & 901 & 900 & 4.1 & 0.81 \\
\hline $\mathrm{CP}$ & 190 & 189 & 6.0 & 0.90 \\
\hline $\mathrm{NDF}$ & 267 & 260 & 9.5 & 0.45 \\
\hline $\mathrm{ADF}$ & 174 & 166 & 8.9 & 0.37 \\
\hline Ether extract & 58 & 57 & 4.1 & 0.74 \\
\hline \multicolumn{5}{|l|}{ FA profile, $\mathrm{g} / 100 \mathrm{~g}$ of total $\mathrm{FA}$} \\
\hline 14:0 & 0.79 & 1.66 & 0.029 & $<0.001$ \\
\hline $16: 0$ & 11.99 & 14.06 & 0.743 & 0.03 \\
\hline 18:0 & 3.67 & 3.48 & 0.134 & 0.22 \\
\hline cis-9 18:1 & 22.30 & 19.94 & 1.404 & 0.14 \\
\hline cis-9,cis-12 18:2 & 46.22 & 42.37 & 1.511 & 0.04 \\
\hline cis-9, cis- 12, cis-15 18:3 & 4.53 & 4.91 & 0.538 & 0.50 \\
\hline cis- 4, cis- 7, cis- 10, cis- 13, cis- $1622: 5$ & 0.00 & 0.71 & 0.037 & $<0.001$ \\
\hline cis-4,cis-7,cis-10,cis-13,cis-16,cis-19 22:6 & 0.00 & 1.87 & 0.097 & $<0.001$ \\
\hline
\end{tabular}

${ }^{1}$ Refers to TMR containing $25 \mathrm{~g}$ of sunflower oil $/ \mathrm{kg}$ of DM and supplemented with 0 (SO; control diet) or $8 \mathrm{~g}$ of marine algae (SOMA diet) $/ \mathrm{kg}$ of DM.

${ }^{2} \mathrm{SED}=$ standard error of the difference.

${ }^{3}$ Contained $(\mathrm{g} / \mathrm{kg}): \mathrm{NaHCO}_{3}$ (458.3), $\mathrm{CaCO}_{3}$ (250.0), $\mathrm{NaCl}$ (125.0), minerals and vitamins (104.2), and wheat bran (62.5).

${ }^{4}$ Contained (g/100 g of FA): 16:0 (5.5), 18:0 (4.4), 18:1 n-9 (36.4), and 18:2 n-6 (50.3).

${ }^{5}$ As declared by the supplier (Martek Biosciences Corp., Columbia, MD), marine algae (DHA Gold Animal Feed Ingredient) contained (g/kg of DM): OM (912), CP (167), crude fiber (45), and ether extract (558). Fatty acid composition (\% of FFA): 14:0 (8.5), 16:0 (23.2), 20:3 n-6 (1.6), 20:5 n-3 (1.9), 22:5 n-6 (17.7), and 22:6 n-3 (42.3).

ture (e.g., Shingfield et al., 2003; Kramer et al., 2008), and by comparison with milk samples for which the FA composition was determined based on GC analysis of FAME and GC-MS analysis of corresponding 4,4-dimethyloxazoline derivates.

\section{Statistical Analysis}

All data were analyzed by repeated-measures ANOVA for a completely randomized design, using the MIXED procedure of SAS (version 9.2; SAS Institute Inc., Cary, $\mathrm{NC}$ ) and assuming a covariance structure based on Schwarz's Bayesian information model fit criteria. The statistical model included the fixed effects of diet (D), time $(\mathrm{T})$, their interaction $(\mathrm{D} \times \mathrm{T})$, and the initial record measured at $0 \mathrm{~d}$ (covariate), as follows:

$$
y_{i j k}=\mu+\alpha_{i}+d_{j(i)}+\delta_{k}+(\alpha \delta)_{i k}+\left(b+\varphi_{j}\right) x_{i j}+\mathrm{e}_{i j k},
$$

where $y_{i j k}$ is the dependent variable measured at time $k$ on the $j$ th lot assigned to the $i$ th diet, $\mu$ the overall mean effect, $\alpha_{i}$ the $i$ th fixed diet effect, $d_{j(i)}$ the random effect of the $j$ th lot (subjects) within the $i$ th diet, $\delta_{k}$ the fixed $k$ th time effect, $(\alpha \delta)_{i k}$ the fixed interaction effect between diet and time, $b$ the common regression coefficient of initial value of $x_{i j}, \varphi_{j}$ the slope deviation of the ith diet from common slope $b, x_{i j}$ the initial record measure of lot $j$ on diet $i$ at the beginning of the experiment, and $\mathrm{e}_{i j k}$ the random error associated with the $j$ th lot assigned to the $i$ th diet at time $k$. Significant differences were declared at $P<0.05$ and tendencies accepted if $P<0.10$. Least squares means (adjusted for the covariance) are reported throughout.

\section{RESULTS}

\section{Animal Performance and Milk Composition}

To better illustrate the persistency of the response to MA supplementation, figures depict comparisons not only between treatments at each sampling time, but also among d 0 (control), d 6 (short term), d 24 (medium term), and d 54 (long term). 
Table 2. Dry matter intake, milk yield, and milk composition in ewes fed the experimental diets ${ }^{1}$

\begin{tabular}{|c|c|c|c|c|c|c|}
\hline Item & \multicolumn{2}{|c|}{ Treatment } & $\mathrm{SED}^{2}$ & \multicolumn{3}{|c|}{$P$-value ${ }^{3}$} \\
\hline DMI, g/d & 2,651 & 2,651 & 103.9 & 0.99 & $<0.001$ & 0.05 \\
\hline Milk & 2,081 & 2,069 & 155.1 & 0.94 & $<0.001$ & 0.86 \\
\hline Fat & 132.0 & 118.5 & 4.00 & 0.04 & $<0.001$ & 0.01 \\
\hline Protein & 101.9 & 102.0 & 3.21 & 0.98 & $<0.001$ & 0.39 \\
\hline \multicolumn{7}{|c|}{ Composition, $\mathrm{g} / 100 \mathrm{~g}$ of raw milk } \\
\hline Fat & 6.29 & 5.61 & 0.221 & 0.04 & $<0.001$ & 0.008 \\
\hline Protein & 4.97 & 4.88 & 0.151 & 0.58 & 0.13 & 0.19 \\
\hline Lactose & 4.98 & 4.96 & 0.089 & 0.83 & $<0.001$ & 0.60 \\
\hline $\mathrm{TS}$ & 17.16 & 16.35 & 0.323 & 0.07 & $<0.001$ & 0.03 \\
\hline
\end{tabular}

${ }^{1}$ Refers to TMR containing $25 \mathrm{~g}$ of sunflower oil/kg of DM and supplemented with 0 (SO; control diet) or $8 \mathrm{~g}$ of marine algae (SOMA diet)/ $\mathrm{kg}$ of DM.

${ }^{2} \mathrm{SED}=$ standard error of the difference.

${ }^{3}$ Probability of significant effect of experimental diet $(\mathrm{D})$, time on $\operatorname{diet}(\mathrm{T})$, and their interaction $(\mathrm{D} \times \mathrm{T})$.

Supplementation with MA did not affect milk yield but decreased fat content $(P<0.05$; Table 2). Differences were detected from d 18 onward (see Figure 1) and reached $-17 \%$ at the end of the experiment (d 54). A negative effect of MA addition was also observed on milk fat yield $(P<0.05)$, whereas DMI and protein, lactose, and TS yields were not affected $(P>0.10)$.

\section{Milk FA Profile}

Dietary supplementation with SOMA resulted in marked variation of milk FA composition relative to the control (SO) diet (see Table 3 and Supplemental Table $\mathrm{S} 1$, available at http://www.journalofdairyscience. org/). For most FA, the response to the addition of MA varied with time on diet, whereas the FA profile of milk from control ewes remained relatively constant throughout the trial, as shown in Figure 1.

Inclusion of MA had no significant effect on the molar proportions of FA with fewer or more than 16 carbon atoms, but it did cause a reduction in the daily molar yield of FA that was comparable between those synthesized de novo or from plasma uptake (on average $-15 \%$ vs. $-12 \%$, respectively; Table 3 ). Addition of MA decreased the concentration (g/100 g of total FA) of SFA $(P<0.001)$, mainly due to the substantial reduction of 18:0 (-56\%). This response was evident from the first measurement (d 6) and persisted at a relatively constant level during the experimental period (Figure 1). The SOMA treatment affected the proportion of several odd- and branched-chain FA and increased that of saturated oxo-FA, especially 10-O-18:0 $(P<0.001)$.

Supplementation with MA reduced the content of cis-9 18:1 $(P<0.001)$, the changes with time on diet being very similar to that explained above for 18:0, although $\Delta^{9}$-desaturase indices were not significantly affected (data not shown). In contrast, MA addition enhanced total trans MUFA $(P=0.001)$, especially trans-10 and trans-11 18:1 isomers but also several others (e.g., trans- 4 , trans-5, trans $-6+7+8$, trans- 9 , and trans-12 18:1). The content of trans-10 18:1 in the SOMA treatment increased continuously throughout the experiment and reached the greatest difference compared with the control on d 54 (244\%). The isomer trans-11 18:1 increased quickly and reached the highest level of enrichment on d 6, but then declined until d 24 and remained stable thereafter. For both isomers, no differences among days were detected in animals fed the SO diet.

Supplementation with MA increased total CLA concentration $(P<0.001)$, without affecting significantly that of total nonconjugated 18:2. The content of cis-9,trans-11 18:2 increased rapidly in animals on the SOMA treatment, showing the maximum difference compared with SO on d 6 (94\%) and decreasing gradually to $46 \%$ on d 54 . Its milk content did not vary over time in ewes fed the control diet $(P>0.10)$. Two other CLA isomers, trans-10,cis-12 and trans-9,cis-11 18:2, also increased with the SOMA diet, and their response persisted throughout the trial. However, comparisons with the SO diet were only significant at some individual sampling times, probably because of the large variation within treatments.

Most nonconjugated 18:2 tended to be enhanced by the addition of MA, although linoleic acid was always greater in ewes on SO than on SOMA diets $(P<$ 0.001), and its temporal pattern was similar with both treatments.

Supplementation of the diet with MA caused a significant increase $(P<0.001)$ in long-chain n-3 PUFA (e.g., 

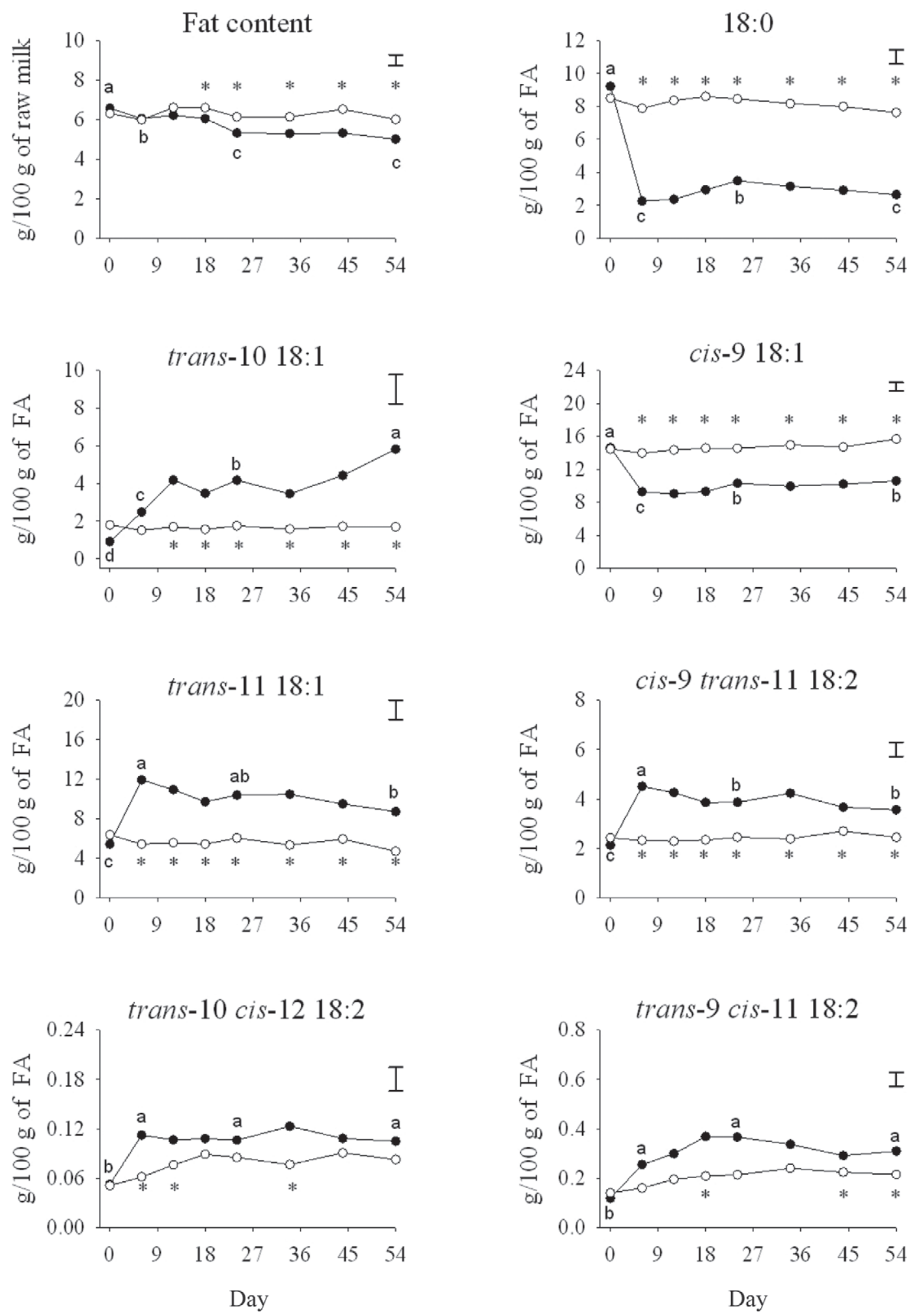

Figure 1. Temporal changes in milk fat content (g/100 g of raw milk) and 18:0, trans-10 18:1, cis-9 18:1, trans-11 18:1, cis-9,trans-11 18:2, trans-10,cis-12 18:2, and trans-9,cis-11 18:2 content (g/100 g of total FA) in ewes fed a TMR containing $25 \mathrm{~g}$ of sunflower oil/kg of DM and supplemented with 0 (SO; control diet; $\mathrm{O})$ or $8 \mathrm{~g}$ of marine algae (SOMA; $) / \mathrm{kg}$ of DM. Values are the mean from 3 lots of 6 animals per lot; vertical bars represent the SE of the difference. ${ }^{*}$ Differences $(P<0.05)$ between SO and SOMA treatments; ${ }^{\mathrm{a}-\mathrm{C}}$ Differences $(P<0.05)$ in SOMA treatment among d 0,6, 24, and 54 . 
Table 3. Fatty acid composition of milk from ewes fed the experimental $\operatorname{diets}^{1}$ (for a complete profile, please see Supplemental Table S1, available at http://www.journalofdairyscience.org/)

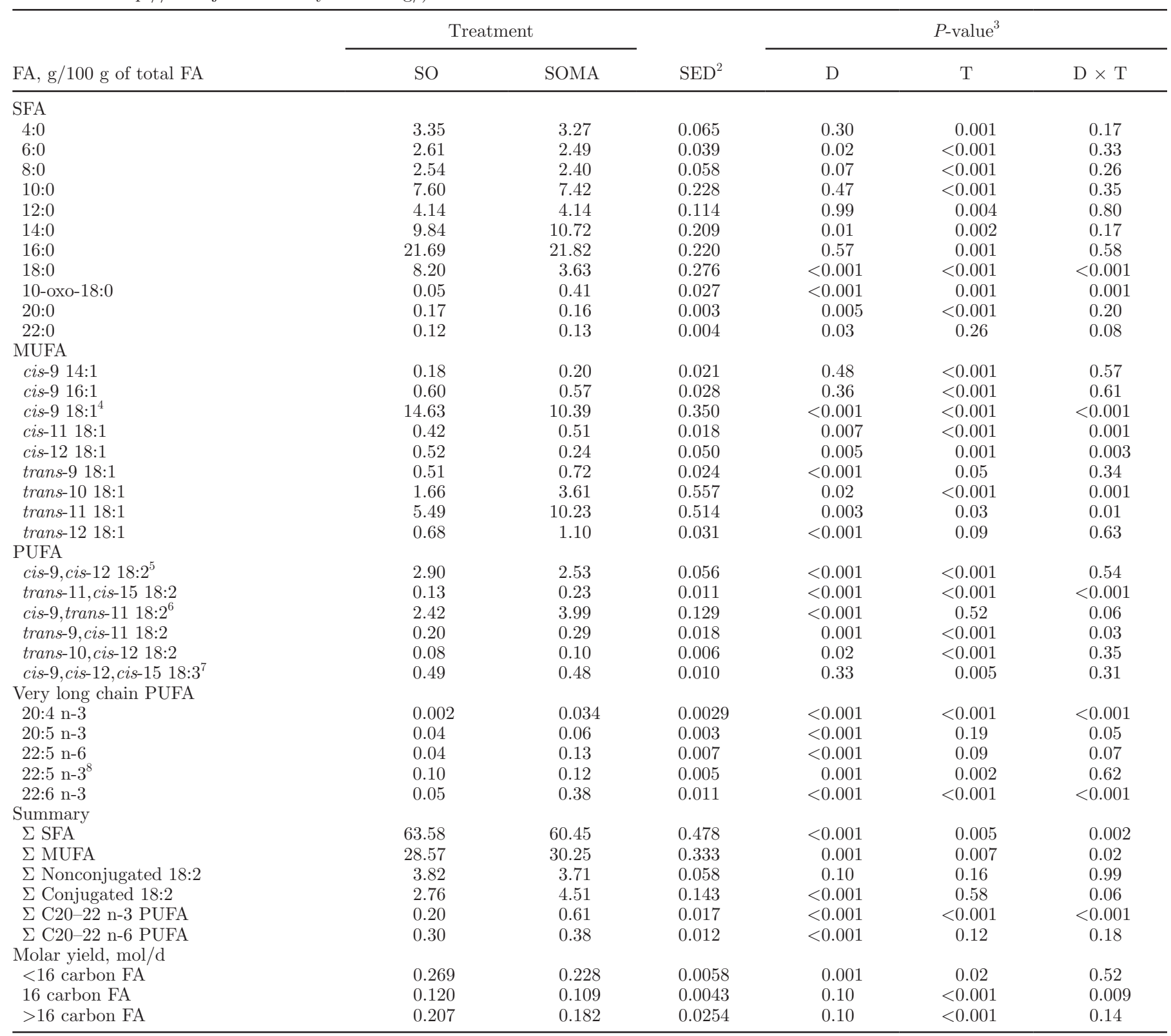

${ }^{1}$ Refers to TMR containing $25 \mathrm{~g}$ of sunflower oil/kg of DM and supplemented with 0 (SO; control diet) or $8 \mathrm{~g}$ of marine algae (SOMA diet)/ $\mathrm{kg}$ of DM.

${ }^{2} \mathrm{SED}=$ standard error of the difference.

${ }^{3}$ Probability of significant effect of experimental diet $(\mathrm{D})$, time on $\operatorname{diet}(\mathrm{T})$, and their interaction $(\mathrm{D} \times \mathrm{T})$.

${ }^{4}$ Coelutes with trans-13+14 18:1.

${ }^{5}$ Coelutes with 9,15 18:2.

${ }^{6}$ Coelutes with trans-7,cis-9 18:2 + cis-14 20:1.

${ }^{7}$ Coelutes with cis-11 20:1.

${ }^{8}$ Coelutes with 26:0.

20:3, 20:4, 20:5, 22:5, and 22:6 n-3) and a smaller but still significant increment in $\mathrm{n}-6(P<0.01)$, although the effect on particular FA within this latter group was variable. Inclusion of MA caused a large enrichment in the milk content of docosahexaenoic acid (DHA; $P<0.001$ ), which was gradual during the first $3 \mathrm{wk}$ and stable thereafter. At the end of the experiment (d 54 ), the concentration of DHA was 12 -fold greater in 
the milk from ewes fed the SOMA diet than in milk from ewes on the SO diet, despite the limited transfer efficiency from diet to milk (about 15\%).

\section{DISCUSSION}

Long-term effects of dietary marine n-3 PUFA on milk FA composition have been investigated in dairy cows (AbuGhazaleh and Holmes, 2007; Mohammed et al., 2011). However, reports on the persistency of the response to diet addition of marine lipids are still limited for dairy sheep.

Supplementation with marine lipids often decreases DMI in sheep (Papadopoulos et al., 2002; Reynolds et al., 2006; Toral et al., 2010a), although the low amount of MA used in the present study did not affect this parameter, and the literature provides evidence of no changes with higher doses of MA or fish oil (Capper et al., 2007; Toral et al., 2010b). Milk fat depression induced by marine lipids has only been reported when ewes are fed high-concentrate diets (Capper et al., 2007; Toral et al., 2010a,b), but information on its persistency is limited to just $4 \mathrm{wk}$. The results of the present study show that the MFD not only persisted but also increased progressively over the 8-wk experiment (see Figure 1).

As expected, diet supplementation with MA resulted in significant alterations in milk FA composition (Franklin et al., 1999; Reynolds et al., 2006; Boeckaert et al., 2008a). The discussion of these changes and their temporal profiles will be focused mainly on those FA potentially modified by altered rumen microbial biohydrogenation and previously related to MFD. Starting with 18:0 and cis-9 18:1, the marked decline in their milk concentration was consistent with changes in the FA profile observed not only in milk (Loor et al., 2005b; Gama et al., 2008; Toral et al., 2010b) but also in rumen digesta from cows and ewes fed marine lipids (Boeckaert et al., 2008b; Or-Rashid et al., 2008; Toral et al., 2012), because marine PUFA inhibit the complete biohydrogenation of unsaturated FA and result in a decrease in the ruminal outflow of 18:0. A lower availability of this FA for endogenous synthesis, via $\Delta^{9}$-desaturation, of cis-9 18:1 may play a key role in MFD in animals consuming marine lipids (Loor et al., 2005b; Shingfield and Griinari, 2007). Oleic acid, in fact, has been indicated as one of the principal FA responsible for the maintenance of fluidity of milk fat globules in the mammary gland and, consequently, for their secretion (Timmen and Patton, 1988; Gama et al., 2008).

The lower content of 18:0 and cis-9 18:1 persisted until the end of the trial, which is in line with a previous study in cows fed MA for $20 \mathrm{~d}$ (Boeckaert et al., 2008a), but disagrees with the transient changes reported in cows fed fish oil and SO (Shingfield et al., 2006). Variations in the amount and form of the lipid supplement and in the basal diet composition, as well as inter-species differences, might explain that different behavior over an extended period.

Results also showed an increase in milk trans 18:1 isomers, especially in trans-10 18:1, which arises from alternative pathways of biohydrogenation due to changes in rumen bacterial populations (Boeckaert et al., 2008b; Toral et al., 2012) and increased gradually throughout the whole experiment. This pattern was unexpected given the decrease observed by Toral et al. (2010b) and would refute the hypothesis of an adaptation of the rumen microbiota to the consumption of MA.

Although some controversy still exists in the literature (Lock et al., 2007; Shingfield et al., 2009), trans-10 18:1 has been related not only to MFD but also to a long-term persistency in cows fed fish oil (Shingfield et al., 2006; AbuGhazaleh and Holmes, 2007; Mohammed et al., 2011). In the present study, the evolution of this biohydrogenation intermediate followed an opposite trend to that observed for the concentration of milk fat (see Figure 1). However, previous studies in dairy sheep showed greater levels of trans-10 18:1 without concomitant reductions in milk fat synthesis (Reynolds et al., 2006; Gómez-Cortés et al., 2008), which would rule out this FA as the principal factor responsible for the observed MFD and suggest that other biohydrogenation intermediates should also contribute to the reduction in milk fat.

Evaluation of several studies indicates that 2 CLA isomers, trans-10,cis-12 18:2 and trans-9,cis-11 18:2, exert MFD effects in dairy cows and sheep (Lock et al., 2006; Shingfield and Griinari, 2007; Sinclair et al., 2010), although the concentration of the former showed no change in dairy ewes suffering from marine lipidinduced MFD (Toral et al., 2010a,b). In the present experiment, both CLA isomers increased with treatment and their response persisted until the end of the trial, although they were not strongly correlated with the content of milk fat in ewes on the SOMA diet.

As expected, inclusion of MA also induced an enrichment of the milk in some bioactive components, such as trans-11 18:1, cis-9,trans-11 18:2, and DHA (Papadopoulos et al., 2002; Reynolds et al., 2006; Toral et al., 2010b). With respect to very long chain PUFA, the content of DHA reached a maximum by the end of the third week of MA addition and then remained relatively constant, which is consistent with previous findings in sheep and cows (Papadopoulos et al., 2002; Reynolds et al., 2006; Boeckaert et al., 2008a). The slight but significant increase observed in n-6 PUFA 
was due to the higher content of 22:5 n-6, attributable to its supply with MA (Mohammed et al., 2011).

Several milk odd- and branched chain-FA, which are largely derived from bacteria leaving the rumen and are therefore thought to reflect rumen function (Vlaeminck et al., 2006), were affected by dietary MA. Although this is in line with variations observed in the rumen digesta of lactating ewes fed SOMA (Toral et al., 2012), most changes (e.g., the increase in odd-chain iso FA, such as 17:0 iso) were only moderate compared with those reported in dairy cows (Shingfield et al., 2003, 2006; Boeckaert et al., 2008a). The increment in saturated oxo-FA was also consistent with changes in rumen bacterial populations in response to the presence of marine lipids and with the consequent shifts in biohydrogenation pathways (Toral et al., 2010c, 2012). The fact that most of these differences persisted throughout the experimental period supports that the rumen microbiota did not adapt to the consumption of MA, thus challenging the initial hypothesis.

\section{CONCLUSIONS}

The gradual and persistent increase in trans 18:1 isomers and the reduced availability of 18:0 for endogenous synthesis of cis-9 18:1 seem to play a key role in the persistency of MFD in lactating ewes fed marine algae. Further studies, however, are required to elucidate the mechanisms underlying this response in dairy sheep. The fact that the persistency lasted until the end of the monitored period (54 d) suggests that the rumen microbiota failed to adapt to dietary supply of very long chain n-3 PUFA, as hypothesized.

\section{ACKNOWLEDGMENTS}

This work was funded by the Spanish Ministry of Economy and Competitiveness (MINECO; AGL201123700). E. Bichi gratefully acknowledges receipt of a predoctoral grant from the Spanish National Research Council (CSIC; JAE Programme) supported by European Social Fund. The authors thank K. J. Shingfield and V. Toivonen (MTT Agrifood Research Finland, Jokioinen, Finland) for invaluable help with FA identification. We also thank the research farm staff from the Instituto de Ganadería de Montaña (León, Spain) for their help in the fieldwork.

\section{REFERENCES}

AbuGhazaleh, A. A., and L. D. Holmes. 2007. Diet supplementation with fish oil and sunflower oil to increase conjugated linoleic acid levels in milk fat of partially grazing dairy cows. J. Dairy Sci. 90:2897-2904.
AOAC International. 2006. Official Methods of Analysis of AOAC International. 18th ed. 1st rev. AOAC Int., Gaithersburg, MD.

AOCS (American Oil Chemists' Society). 2008. Official Methods and Recommended Practices of the American Oil Chemists' Society. 5th ed. 2nd printing. AOCS, Urbana, IL.

Boeckaert, C., B. Vlaeminck, J. Dijkstra, A. Issa-Zacharia, T. Van Nespen, W. Van Straalen, and V. Fievez. 2008a. Effect of dietary starch or micro algae supplementation on rumen fermentation and milk fatty acid composition of dairy cows. J. Dairy Sci. 91:47144727.

Boeckaert, C., B. Vlaeminck, V. Fievez, L. Maignien, J. Dijkstra, and N. Boon. 2008b. Accumulation of trans C-18:1 fatty acids in the rumen after dietary algal supplementation is associated with changes in the Butyrivibrio community. Appl. Environ. Microbiol. 74:6923-6930.

Capper, J. L., R. G. Wilkinson, A. M. Mackenzie, and L. A. Sinclair. 2007. The effect of fish oil supplementation of pregnant and lactating ewes on milk production and lamb performance. Animal 1:889-898.

Franklin, S., K. Martin, R. Baer, D. Schingoethe, and A. Hippen. 1999 Dietary marine algae (Schizochytrium sp.) increases concentrations of conjugated linoleic, docosahexaenoic and transvaccenic acids in milk of dairy cows. J. Nutr. 129:2048-2054.

Gama, M. A. S., P. C. Garnsworthy, J. M. Griinari, P. R. Leme, P. H. M. Rodrigues, L. W. O. Souza, and D. P. D. Lanna. 2008. Dietinduced milk fat depression: Association with changes in milk fatty acid composition and fluidity of milk fat. Livest. Sci. 115:319-331.

Gebauer, S. K., J. M. Chardigny, M. U. Jakobsen, B. Lamarche, A. L. Lock, S. D. Proctor, and D. J. Baer. 2011. Effects of ruminant trans fatty acids on cardiovascular disease and cancer: A comprehensive review of epidemiological, clinical, and mechanistic studies. Adv. Nutr. 2:332-354.

Gómez-Cortés, P., P. Frutos, A. R. Mantecón, M. Juárez, M. A. de la Fuente, and G. Hervás. 2008. Milk production, conjugated linoleic acid content, and in vitro ruminal fermentation in response to high levels of soybean oil in dairy ewe diet. J. Dairy Sci. 91:1560-1569.

Griinari, J., D. Dwyer, M. McGuire, D. Bauman, D. Palmquist, and K. Nurmela. 1998. Trans-octadecenoic acids and milk fat depression in lactating dairy cows. J. Dairy Sci. 81:1251-1261.

ISO (International Organization for Standardization). 1999a. Animal feeding stuffs - Determination of moisture and other volatile matter content. ISO 6496:1999. ISO, Geneva, Switzerland.

ISO (International Organization for Standardization). 1999b. Whole milk-Determination of milkfat, protein and lactose contentGuidance on the operation of mid-infrared instruments. ISO 9622:1999. ISO, Geneva, Switzerland.

ISO (International Organization for Standardization). 2002. Animal feeding stuffs - Determination of crude ash. ISO 5984:2002. ISO, Geneva, Switzerland

ISO (International Organization for Standardization). 2009. Animal feeding stuffs-Determination of nitrogen content and calculation of crude protein content - Part 2: Block digestion and steam distillation method. ISO 5983-2:2009. ISO, Geneva, Switzerland.

Kramer, J. K. G., M. Hernandez, C. Cruz-Hernandez, J. Kraft, and M. E. R. Dugan. 2008. Combining results of two GC separations partly achieves determination of all cis and trans 16:1, 18:1, 18:2 and 18:3 except CLA isomers of milk fat as demonstrated using Ag-ion SPE fractionation. Lipids 43:259-273.

Lock, A. L., B. M. Teles, J. W. Perfield II, D. E. Bauman, and L. Sinclair. 2006. A conjugated linoleic acid supplement containing trans-10, cis-12 reduces milk fat synthesis in lactating sheep. J. Dairy Sci. 89:1525-1532.

Lock, A. L., C. Tyburczy, D. A. Dwyer, K. J. Harvatine, F. Destaillats, Z. Mouloungui, L. Candy, and D. E. Bauman. 2007. Trans-10 octadecenoic acid does not reduce milk fat synthesis in dairy cows. J. Nutr. 137:71-76.

Loor, J., M. Doreau, J. Chardigny, A. Ollier, J. Sébédio, and Y. Chilliard. 2005b. Effects of ruminal or duodenal supply of fish oil on milk fat secretion and profiles of trans-fatty acids and conjugated linoleic acid isomers in dairy cows fed maize silage. Anim. Feed Sci. Technol. 119:227-246. 
Loor, J. J., A. Ferlay, A. Ollier, M. Doreau, and Y. Chilliard. 2005a. Relationship among trans and conjugated fatty acids and bovine milk fat yield due to dietary concentrate and linseed oil. J. Dairy Sci. 88:726-740.

Mertens, D. R. 2002. Gravimetric determination of amylase-treated neutral detergent fiber in feeds with refluxing in beakers or crucibles: Collaborative study. J. AOAC Int. 85:1217-1240.

Mohammed, R., R. G. Khorasani, L. A. Goonewardene, J. K. G. Kramer, and J. J. Kennelly. 2011. Persistency of milk trans-18:1 isomers and rumenic acid in Holstein cows over a full lactation. Can. J. Anim. Sci. 91:147-167.

Or-Rashid, M. M., J. K. G. Kramer, M. A. Wood, and B. W. McBride. 2008. Supplemental algal meal alters the ruminal trans-18:1 fatty acid and conjugated linoleic acid composition in cattle. J. Anim. Sci. 86:187-196.

Papadopoulos, G., C. Goulas, E. Apostolaki, and R. Abril. 2002. Effects of dietary supplements of algae, containing polyunsaturated fatty acids, on milk yield and the composition of milk products in dairy ewes. J. Dairy Res. 69:357-365.

Perfield, J. W. II, A. L. Lock, J. M. Griinari, A. Sæbø, P. Delmonte, D. A. Dwyer, and D. E. Bauman. 2007. Trans-9, cis-11 conjugated linoleic acid reduces milk fat synthesis in lactating dairy cows. J. Dairy Sci. 90:2211-2218.

Reynolds, C. K., V. L. Cannon, and S. C. Loerch. 2006. Effects of forage source and supplementation with soybean and marine algal oil on milk fatty acid composition of ewes. Anim. Feed Sci. Technol. 131:333-357.

Shingfield, K., S. Ahvenjärvi, V. Toivonen, A. Äröla, K. Nurmela, P. Huhtanen, and J. Griinari. 2003. Effect of dietary fish oil on biohydrogenation of fatty acids and milk fatty acid content in cows. Anim. Sci. 77:165-179.

Shingfield, K. J., and J. M. Griinari. 2007. Role of biohydrogenation intermediates in milk fat depression. Eur. J. Lipid Sci. Technol. 109:799-816.

Shingfield, K. J., C. K. Reynolds, G. Hervás, J. M. Griinari, A. S. Grandison, and D. E. Beever. 2006. Examination of the persis- tency of milk fatty acid composition responses to fish oil and sunflower oil in the diet of dairy cows. J. Dairy Sci. 89:714-732.

Shingfield, K. J., A. Sæbø, P.-C. Sæbø, V. Toivonen, and J. M. Griinari. 2009. Effect of abomasal infusions of a mixture of octadecenoic acids on milk fat synthesis in lactating cows. J. Dairy Sci. 92:4317-4329.

Sinclair, L. A., W. M. P. B. Weerasinghe, R. C. Wilkinson, M. J. de Veth, and D. E. Bauman. 2010. A supplement containing trans-10 cis-12 conjugated linoleic acid reduces milk fat yield but does not alter organ weight or body fat deposition in lactating ewes. J. Nutr. 140:1949-1955.

Timmen, H., and S. Patton. 1988. Milk fat globules: Fatty-acid composition, size and in vivo regulation of fat liquidity. Lipids 23:685689.

Toral, P. G., A. Belenguer, K. J. Shingfield, G. Hervás, V. Toivonen, and P. Frutos. 2012. Fatty acid composition and bacterial community changes in the rumen fluid of lactating sheep fed sunflower oil plus incremental levels of marine algae. J. Dairy Sci. 95:794-806.

Toral, P. G., P. Frutos, G. Hervás, P. Gómez-Cortés, M. Juárez, and M. A. de la Fuente. 2010a. Changes in milk fatty acid profile and animal performance in response to fish oil supplementation, alone or in combination with sunflower oil, in dairy ewes. J. Dairy Sci. 93:1604-1615.

Toral, P. G., G. Hervás, P. Gómez-Cortés, P. Frutos, M. Juárez, and M. A. de la Fuente. 2010b. Milk fatty acid profile and dairy sheep performance in response to diet supplementation with sunflower oil plus incremental levels of marine algae. J. Dairy Sci. 93:16551667

Toral, P. G., K. J. Shingfield, G. Hervás, V. Toivonen, and P. Frutos. 2010c. Effect of fish oil and sunflower oil on rumen fermentation characteristics and fatty acid composition of digesta in ewes fed a high concentrate diet. J. Dairy Sci. 93:4804-4817.

Vlaeminck, B., V. Fievez, A. R. J. Cabrita, A. J. M. Fonseca, and R. J. Dewhurst. 2006. Factors affecting odd- and branched-chain fatty acids in milk: A review. Anim. Feed Sci. Technol. 131:389-417. 